\title{
Predicting ectotherm vulnerability to climate warming: Comparing preferred and actual body temperatures in Pseudemoia entrecasteauxii
}

\author{
Julia Hammer, Hannah Zurcher, Christine Mauger, Chen Liang, \\ Ming-Dao Chia, Tess Walsh-Rossi, Angela Stoddard, Cameron \\ McArthur, Sarah Stock
}

\section{Abstract}

The performance of ectotherms can be related to temperature: performance increases with temperature to a certain optimum, above which it quickly drops. Climate warming is a threat to tropical ectotherms, whose thermal optima are relatively low. Temperate and alpine ectotherms, in contrast, have higher thermal optima, and therefore may benefit from rising temperatures. The preferred body temperatures $\left(T_{p}\right)$ and field body temperatures $\left(T_{b}\right)$ of viviparous Australian alpine skink, Pseudemoia entrecasteauxii (Duméril and Bibron), were compared. Results showed that $\mathrm{T}_{\mathrm{p}}$ was lower than $\mathrm{T}_{\mathrm{b}}$ in early summer, implying that short-term warming could enhance performance. These thermal performance parameters are one of many factors that require consideration when predicting the vulnerability of ectotherms to climate warming.

\section{Introduction}

Climate warming presents a permanent and pervasive challenge to organisms worldwide (IPCC 2015; Parmesan 2006). Consequently, biologists are interested in developing conservation and management strategies that prioritise vulnerable species (Williams et al. 2008). 
Ectotherms are arguably the most sensitive to warming, since performance depends on body temperature, and body temperature depends on the environment (Angilletta et al. 2002). Ectotherms operate at body temperatures $\left(\mathrm{T}_{\mathrm{b}}\right)$ between specific critical thermal minima $\left(\mathrm{CT}_{\min }\right)$ and maxima $\left(\mathrm{CT}_{\max }\right.$; Huey et al. 2012). Within those limits, performance is highest at a certain optimal temperature $\left(\mathrm{T}_{\mathrm{o}}\right)$, but most ectotherms thermoregulate to a preferred body temperature $\left(\mathrm{T}_{\mathrm{p}}\right)$ just below this optimum. When $\mathrm{T}_{\mathrm{b}}<\mathrm{CT}_{\text {min }}$, performance gradually lessens, but when $\mathrm{T}_{\mathrm{b}}>\mathrm{CT}_{\max }$, performance rapidly drops to lethality. The extent to which an ectotherm is vulnerable to climate warming depends on whether it is currently achieving or exceeding $T_{p}\left(T_{b} \geq T_{p}\right)$, or not achieving $\mathrm{T}_{\mathrm{p}}\left(\mathrm{T}_{\mathrm{b}}<\mathrm{T}_{\mathrm{p}}\right)$ : if the former were true, climate warming would push $\mathrm{T}_{\mathrm{b}}^{\mathrm{p}}$ towards $\mathrm{C}_{\text {max }}^{\mathrm{p}}$, reducing performance and restricting activity, but if the latter were true, warming would bring $T_{b}$ closer to $T_{p}$, enhancing performance and enabling extended activity (Huey et al. 2012).

Highland ectotherms are exposed to cooler, more variable temperatures than tropical ectotherms, thus selection should favour broader thermal tolerance in alpine areas compared to the tropics (Janzen 1967). Indeed, recent analyses suggest that tropical lizards are more in danger of extinction due to climate warming (Sinervo et al. 2010) than temperate and alpine lizards (Aguado and Braña 2014; Caldwell et al. 2015). Nevertheless, thermal performance curves vary between species, and whether all temperate lizards benefit from short-term climate warming remains unclear (reviewed in Clusella-Trullas and Chown 2014). The present study compared $\mathrm{T}_{\mathrm{p}}$ and $\mathrm{T}_{\mathrm{b}}$ in the Australian alpine skink Pseudemoia entrecasteauxii (Duméril and Bibron 1839) to evaluate its vulnerability to future climate warming.

Pseudemoia entrecasteauxii are found in south-east Australian forests and grasslands (Cogger 2014). They are active roughly between December and March (Pengilley 1972 cited in Stapley 2006), during which they progress through viviparous reproductive stages-autumn spermatogenesis and mating (sperm storage over winter hibernation) and spring/summer births (Murphy et al. 2006). Both sexes must monitor food consumption to meet the energy demands of each stage, and gravid females must carefully thermoregulate to maximise performance (high $\mathrm{T}_{\mathrm{o}}$ ) and embryonic survival (low T; Beuchat and Ellner 1987). If climate warming results in $\mathrm{T}_{\mathrm{b}}>\mathrm{CT}_{\max }$ during spring/summer, fecundity would suffer; however, if warming pushes a low $T_{b}$ closer to $T_{p}$, then extended foraging time may increase fecundity. Given their complex ecology, and that their active 
months are the hottest of the year (BOM 2015), predicted to get hotter (Worboys and Good 2011), this species provides a compelling system for examining climate warming impacts on ectotherms.

The present study aimed to test whether alpine ectotherms would benefit or not from future climate warming during one part of the year. It was hypothesised that $P$. entrecasteauxii would not be achieving $\mathrm{T}_{\mathrm{p}}\left(\mathrm{T}_{\mathrm{p}}>\mathrm{T}_{\mathrm{b}}\right)$ in early summer, and therefore benefit from future warming.

\section{Methods}

\section{Lizard collection and husbandry}

All materials and equipment were provided by The Australian National University's Research School of Biology. Twelve P. entrecasteauxii (three males, nine females) were collected by hand or with mealworm baits from the Rainbow Lake walking trail in Kosciuszko National Park, midDecember 2015. In the laboratory, lizards were transferred into individual plastic tubs with mesh windows. Tub floors were covered in soil from the capture site. Dishes of water and toilet rolls for shelter were placed inside, but no food was provided. Bright indoor lights were kept on during daylight hours, and temperature was kept at $-20^{\circ} \mathrm{C}$. The lizards were handled by another research party for two days following capture.

\section{Measuring $T_{p}$ and field $T_{b}$}

Preferred body temperature was determined using a thermal gradient. A $150 \mathrm{~cm} \times 30 \mathrm{~cm} \times 15 \mathrm{~cm}$ Perspex chamber with two runs (separated by a Perspex wall) and a removable lid were set up in a quiet room. A linear temperature range from $-7^{\circ} \mathrm{C}$ to $47^{\circ} \mathrm{C}$ was achieved inside the chamber with a heat lamp at one end. Lizards were placed in the thermal chamber in pairs (one per run) and left alone for five minutes to achieve $T_{p}$. Lizard body temperature was measured by pointing an infrared thermal gun (FLUKE 568 or Digitech QM7215) on the dorsal side between the shoulders. This was repeated at midday the following day. Body and substrate temperatures in the field were recorded by pointing an infrared thermal gun at log-or rock-basking $P$. entrecasteauxii along the Rainbow Lake walking trail, also around midday. 


\section{Results}

Mean $T_{p}$ was found to be significantly higher than mean field $T_{b}$ using a Student's $t$-test (Figure $1 ; P<0.001$ ). This suggests that $P$. entrecasteauxii was not achieving $\mathrm{T}_{\mathrm{p}}$ in the field at the time of collection (early summer). Air temperatures (between $23^{\circ} \mathrm{C}$ and $26^{\circ} \mathrm{C}$ ) and substrate temperatures (logs and rocks; $-28^{\circ} \mathrm{C}$ ) were fairly consistent with $\mathrm{T}_{\mathrm{b}}$. Conditions during collection were sunny, partly cloudy and slightly windy.

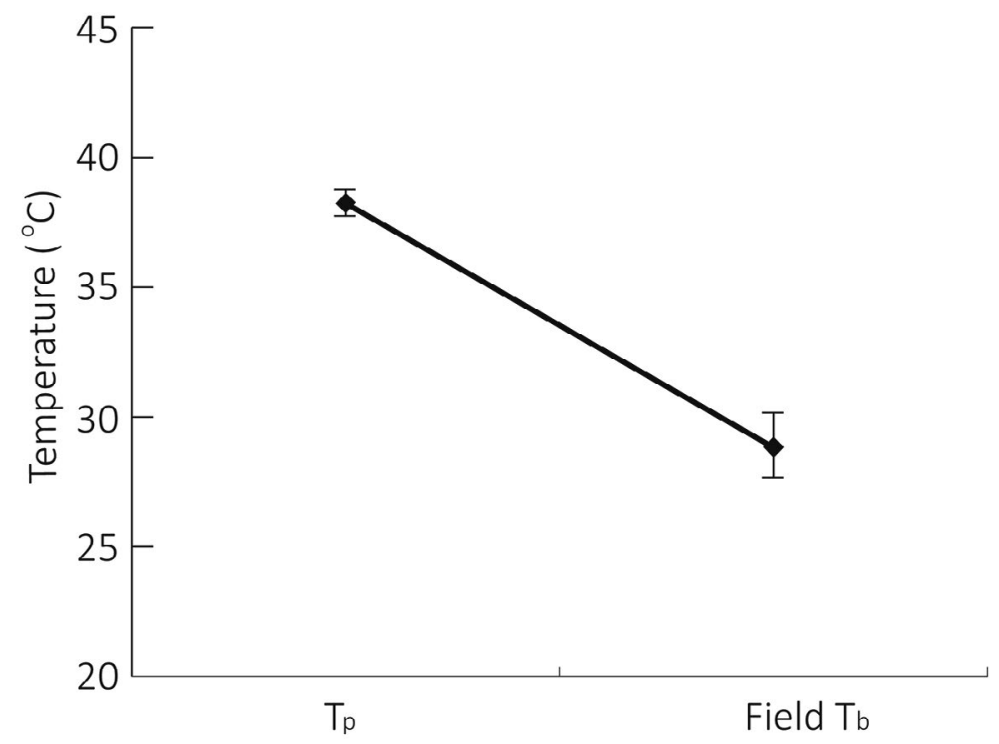

Figure 1: Mean $T_{p}(n=12)$ and field $T_{b}(n=13)$ for $P$. entrecasteauxii, calculated from thermal gradient and field data.

Note: Error bars represent standard error from the mean.

Source: Authors' data.

\section{Discussion}

Pseudemoia entrecasteauxii achieved a lower $\mathrm{T}_{\mathrm{b}}$ than $\mathrm{T}_{\mathrm{p}}$ for early summer, implying that a climate warming-induced increase in $\mathrm{T}_{\mathrm{b}}$ would not be detrimental to reproduction, but rather enhance performance and extend active hours for foraging. This supports the hypothesis that alpine lizards may benefit from short-term warming, and agrees with past research (Aguado and Braña 2014; Caldwell et al. 2015). Nevertheless, several limitations must be noted. 
Sample size was small, and predominantly female. Beal et al. (2014) found that body temperatures of Sceloporous jarrovii varied between sexes: it is possible that the data are only representative of female lizards.

Lizards were left in the thermal gradient for only five minutes, and their body temperatures were measured in a relatively intrusive manner. Stapley (2006) allowed her lizards one month to familiarise themselves with their thermal gradient, and used a thermal camera to collect temperature data. It is possible that the lizards in this study were agitated by handling and human presence such that achieving $\mathrm{T}_{\mathrm{p}}$ was not prioritised.

The current data only describe a few days within a season-it is unknown whether $P$. entrecasteauxii achieve $\mathrm{T}_{\mathrm{p}}$ in autumn and hence also unknown whether climate warming is a year-long benefit.

It is therefore recommended that further research on this topic involve a large and diverse sample size, a thermal gradient in which lizards can comfortably and naturally achieve $\mathrm{T}_{\mathrm{p}}$ with minimal interference, and repeated collections and measurements throughout the active season.

Comparing $T_{p}$ and field $T_{b}$, while useful, is only one of many factors that contribute to ectotherm climate change vulnerability. Others include the extent to which behavioural thermoregulation and microclimate heterogeneity can buffer warming, the plasticity and adaptive potential of thermal performance parameters (i.e. $\mathrm{T}_{\mathrm{p}}$ and $\mathrm{CT}_{\max }$ ), and the impact of biotic and abiotic forces (besides temperature) that result from climate change (Clusella-Trullas and Chown 2014; Huey et al. 2012). For example, Kearney et al. (2009) predict that an increase in air temperature in Australian temperate zones is easily managed by shuttling between sun and shade. Whether P. entrecasteauxii is capable of shuttling through future climate warming is worth investigation. One suggestion is to survey the available temperatures for $P$. entrecasteauxii with absorptive lizard-shaped objects (see Sunday et al. 2014), and model how those temperatures might change with climate warming. According to Huey et al. (2003), ectotherms are incapable of adapting to climate warming due to physiological constraints: thermoregulation allows ectotherms to avoid unwanted temperatures and therefore weakens selection pressures for higher thermal tolerances. Perhaps a close examination of phylogenies (see Clusella-Trullas and Chown 2014) will reveal which lizard families are most at risk. 
In conclusion, it is possible that highland ectotherms, like P. entrecasteauxii, will benefit from short-term climate warming; however, accurately predicting species' responses to climate change requires a broader, more comprehensive approach—a direction for future research.

\section{Acknowledgements}

The authors thank Craig Moritz and Scott Keogh for their guidance, Jack Keogh for lizard-wrangling, the South Alpine Ski Club at Charlotte Pass for their hospitality, and the ANU Research School of Biology for providing all materials and equipment.

\section{References}

Aguado S, Braña F (2014) Thermoregulation in a cold-adapted species (Cyren's Rock Lizard, Iberolacerta cyreni): Influence of thermal environment and associated costs. Canadian Journal of Zoology 92: 955-64. doi.org/10.1139/cjz-2014-0096

Angilletta MJ, Niewiarowski PH, Navas CA (2002) The evolution of thermal physiology in ectotherms. Journal of Thermal Biology 27: 24968. doi.org/10.1016/S0306-4565(01)00094-8

Beal MS, Lattanzio MS, Miles DB (2014) Differences in thermal physiology of adult Yarrow's spiny lizards (Sceloporus jarrovii) in relation to sex and body size. Ecology and Evolution 4: 4220-9. doi. org/10.1002/ece3.1297

BOM (Bureau of Meteorology) (2015) Climate statistics for Australian locations, viewed 18 January 2015, www.bom.gov.au/climate/averages/ tables/cw_071003.shtml

Buechat CA, Ellner S (1987) A quantitative test of life history theory: Thermoregulation by a viviparous lizard. Ecological Monographs 51: 45-60. doi.org/10.2307/1942638

Caldwell AJ, While GM, Beeton NJ, Wapstra E (2015) Potential for thermal tolerance to mediate climate change effects on three members of a cool temperate lizard genus, Niveoscincus. Journal of Thermal Biology 52: 14-23. doi.org/10.1016/j.jtherbio.2015.05.002 
Clusella-Trullas S, Chown SL (2014) Lizard thermal trait variation at multiplescales: A review. Journal of Comparative Physiology 184: 5-21. doi.org/10.1007/s00360-013-0776-x

Cogger H 2014, Reptiles and Amphibians of Australia, 7th edn. CSIRO Publishing, Clayton.

Huey RB, Hertz PE, Sinervo B (2003) Behavioural drive versus behavioural inertia in evolution: A null model approach. The American Naturalist 161: 357-66. doi.org/10.1086/346135

Huey RB, Kearney MR, Krockenberger A, Holtum JAM, Jess M, Williams SE (2012) Predicting organismal vulnerability to climate warming: Roles of behaviour, physiology and adaptation. Philosophical Transactions of the Royal Society B 367: 1665-79. doi.org/10.1098/ rstb.2012.0005

IPCC (2015) Summary for Policymakers. In Climate Change 2014: Synthesis Report, IPCC, viewed 17 January 2016, www.ipcc.ch/pdf/ assessment-report/ar5/syr/SYR_AR5_FINAL_full_wcover.pdf

Kearney M, Shine R, Porter WP (2009) The potential for behavioural thermoregulation to buffer 'cold-blooded' animals against climate warming. Proceedings of the National Academy of Sciences of the United States of America 106: 3835-40. doi.org/10.1073/pnas.0808913106

Murphy K, Hudson S, Shea G (2006) Reproductive seasonality of three cold-temperate viviparous skinks from southeastern Australia. Journal of Herpetology 40, 454-64. doi.org/10.1670/00221511(2006)40[454:RSOTCV]2.0.CO;2

Parmesan C (2006) Ecological and evolutionary responses to recent climate change. Annual Review of Ecology, Evolution, and Systematics 37: 637-69. doi.org/10.1146/annurev.ecolsys.37.091305.110100

Sinervo B, Méndez-de-la-Cruz F, Miles DB, Heulin B, Bastiaans E, Cruz MVS, Lara-Resendiz R, Martínez-Méndez N, Calderón-Espinosa M, De la Riva IJ, Sepulveda PV, Rocha CFD, Ibargüengoytía N, Puntriano CA, Massot M, Lepetz V, Oksanen TA, Chapple DG, Bauer AM, Branch WR, Clobert J, Sites JW (2010) Erosion of lizard diversity by climate change and altered thermal niches. Science 328: 894-9. doi. org/10.1126/science. 1184695 
Stapley J (2006) Individual variation in preferred body temperature covaries with social behaviours and colour in male lizards. Journal of Thermal Biology 31: 362-9. doi.org/10.1016/j.jtherbio.2006.01.008

Sunday JM, Bates AE, Kearney MR, Colwell RK, Dulvy NK, Longino JT, Huey RB (2014) Thermal-safety margins and the necessity of thermoregulatory behaviour across latitude and elevation. Proceedings of the National Academy of Sciences of the United States of America 111: 5610-15. doi.org/10.1073/pnas.1316145111

Williams SE, Shoo LP, Isaac JL, Hoffmann AA, Langham G (2008) Towards an integrated framework for assessing the vulnerability of species to climate change. PLoS Biology 6: 2621-6. doi.org/10.1371/ journal.pbio.0060325

Worboys GL, Good RB (2011) Caring for our Australian Alps Catchments: Summary Report for Policy Makers. Department of Climate Change and Energy Efficiency, Canberra. 
This text is taken from Researching functional ecology in Kosciuszko National Park, edited by Hannah Zurcher, Chia Ming-Dao, Michael Whitehead and Adrienne Nicotra, published 2017 by ANU eView, The Australian National University, Canberra, Australia. dx.doi.org/10.22459/RFEKNP.11.2017.09 